\title{
Die leksikografiese hantering van neo-klassieke en pseudo-sintaktiese komposita*
}

\author{
A.E. van Niekerk, Buro van die Woordeboek van die Afrikannse Taal
}

\begin{abstract}
The Lexicographical Treatment of Neo-classical and Pseudo-syntactic Compounds. The inconsistent treatment of neo-classical and pseudo-syntactic compounds in existing dictionaries can be ascribed mainly to uncertainty about the morphological status of these word-formations and to disregard for their status as compounds. Neo-classical compounds consist of a combination of a (usually) Greek or Latin word element and another element (affix or root). The Greek or Latin elements behave like affixes, but their ability to combine with affixes to form words calls into question their status as affixes. Moreover, the morphological and semantic differences between these elements and affixes are such that the elements could be referred to as neo-classical roots. The lexicographical treatment of the Greek and Latin word elements - these can be Initial Combining Forms (ICFs) or Final Combining Forms (FCFs) - is not based solely on linguistic considerations. For instance, in dictionaries such as the Verklarende Handwoordeboek oan die Afrikanse Taal (HAT) and the Nasionale Woordeboek (NW) the tendency to accord greater lexicographical prominence to initial roots in preference to final roots arises from the traditional word-based structure of dictionaries. Neo-classical roots should be included as sublexical items. The lexicographer should explain relationships in meaning to lexical variants by means of clear cross-references. Neither the HAT nor the NW are consistent in supplying etymological information for foreign word-elements, although this can have a useful encoding value to the dictionary user. Phonological information on variations in 1CFs and accent-placement would also be helpful since this information is not readily predictable. In dealing with sublexical lemmas, the lexicographer should be consistent in the pattern of description, regardless of the status he wants to accord these elements. The lexicographer may neither ignore the productivity of neo-classical compounds, nor arbitrarily include or exclude them. As multi-worded lexical items, the pseudosyntactic compounds form orthographical units as well as units of meaning. As single lexicon items such compounds qualify for inclusion in dictionaries. All rules applying to ordinary lexical items should be followed in the lexicographical treatment of pseudo-syntactic compounds. Thorough contextual guidance, well-considered cross-references and indications of number, which correspond with real language usage are indispensable. It is essential that the inclusion of multiworded lexical items should be both semantically and lexicologically justified. The lexicographical processing of neo-classical and pseudo-syntactic compounds demands a more consistent and circumspect approach. Lexicographers should pay more careful attention to this in future.
\end{abstract}

Hierdie artikel is 'n hoofstuk, met geringe wysigings, uit 'n M.A.-skripsie Die leksikografiese hantering oan komposita wat in Desember 1989 deur die Universiteit van Stellenbosch aanvaar is. 


\section{Keywords: LEXICOGRAPHY, NEO-CLASSICAL COMPOUNDS, PSEUDO-SYNTACTIC COMPOUNDS, SUBLEXICAL LEMMAS}

Opsomming: Die inkonsekwente hantering van neo-klassieke en pseudo-sintaktiese komposita in bestaande woordeboeke kan veral toegeskryf word aan onsekerheid oor die morfologiese status van die genoemde woordvormingsprodukte en die negering van hul kompositumstatus. Neo-klassieke komposita bestaan uit die kombinasie van 'n (gewoonlik) Griekse of Latynse woordelement met 'n ander element (affiks of stam). Die Griekse of Latynse elemente funksioneer soos affikse, maar hul kombineerbaarheid met affikse om woorde te vorm, bring hul affiksstatus in die gedrang. Hierdie elemente verskil boonop morfologies en semanties dusdanig van affikse dat daar na hulle as neo-klassieke stamme verwys kan word. Die leksikografiese hantering van die Griekse en Latynse woordelemente - dit kan begin- of eindkomponente wees - is tot dusver nie op ' $n$ suiwer linguistiese grondslag geplaas nie. Die tendens om in woordeboeke soos die Verklarende Handwoordeboek oan die Afrikaanse Taal (HAT) en Nasionale Woordeboek (NW) groter leksikografiese prominensie aan eerste stamme bo slotstamme te verleen, berus byvoorbeeld op die tradisioneel woordgebaseerde struktuur van woordeboeke. Neo-klassieke stamme behoort as subleksikale lemmas ingesluit te word en waar die genoemde subleksikale items betekenismatig verband hou met leksikale variante, moet die leksikograaf dié betekenisverhouding met behulp van duidelike kruisverwysings ekspliseer. Etimologieleiding word nie in HAT en NW by vreemde woordelemente konsekwent deurgevoer nie, maar kan 'n enkoderende waarde hê en is as sodanig waardevol vir die woordeboekgebruiker. Fonologiese leiding ten opsigte van variasie by beginkomponente of klemplasing is eweneens nultig omdat dié inligting nie geredelik voorspelbaar is nie. Wat die hantering van subleksikale lemmas betref, moet die leksikograaf - ongeag die status wat hy aan dié elemente wil toeken - 'n eenvormige beskrywingspatroon handhaaf. Die leksikograaf durf nie die produktiwiteit van neo-klassieke komposita miskyk en hul insluiting of weglating na willekeur laat geskied nie. Die pseudo-sintaktiese komposita vorm as meerwoordige leksikale items ' $n$ ortografiese en betekeniseenheid. As enkele leksikonitems kwalifiseer dusdanige komposita vir opname in die woordeboek. By die leksikografiese hantering van pseudo-sintaktiese komposita moet alle reëls wat vir gewone leksikale items geld, in aanmerking kom. Deeglike konteksleiding, weldeurdagte kruisverwysings en getalsaanduidings wat met die werklike taalgebruik strook, is onontbeerlik. Die opname van meerwoordige leksikale items moet semanties, maar ook leksikologies gemotiveer kan word. Die leksikografiese bewerking van neo-klassieke en pseudo-sintaktiese komposita ura om 'n benadering wat deur groter konsekwentheid en omsigtigheid gekenmerk word. Hieraan behoort leksikograwe in die toekoms noukeuriger aandag te skenk.

Sleutelwoorde: LEKSIKOGRAFIE, NEO-KLASSIEKE KOMPOSITA, PSEUDO-SINTAKTIESE KOMPOSITA, SUBLEKSIKALE LEMMAS

Die problematiek rondom die leksikografiese hantering van komposita het tot dusver nie genoeg aandag in artikels oor die leksikografie ontvang nie, alhoewel daar al op die tersaaklikheid van die probleem gewys is. Die kwessie is dikwels slegs terloops in die voorwoorde van enkele woordeboeke aangeraik. 
Hierdie artikel is daarop gemik om ' $n$ aantal taalkundige riglyne daar te stel vir die sinvolle hantering van twee tipes komposita, te wete neo-klassieke en pseudosintaktiese komposita. Die genoemde woordvormingsprodukte word nie tradisioneel as komposita gereken nie en is juis daarom in bestaande woordeboeke op 'n lukrake wyse gehanteer. 'n Sinvolle, konsekwente benadering is wenslik en moontlik.

\section{Neo-klassieke komposita}

\subsection{Inleiding}

Bauer (1983: 213) vestig die aandag op 'n soort woord vormingsproses wat tot dusver min aandag in literatuur oor die Engelse morfologie ontvang het. Die genoemde proses was/is ook aktief in Afrikaans werksaam en die produkte daarvan moet deur die leksikograaf vir insluiting in ' $n$ woordeboek oorweeg word.

Dié woordvormingsproses, wat as kompositumvorming of afleiding beskou sou kon word, bestaan uit die kombinasie van 'n (gewoonlik) Griekse of Latynse woordelement met 'n ander element (affiks of stam). Hierdie Griekse of Latynse elemente funksioneer soos affikse, maar toon terselfdertyd eienskappe wat hulle van affikse onderskei. Die Oxford English Dictionary (OED) praat van sodanige elemente as "combining forms" (Bauer 1983: 213), terwyl HAT hulle as "woordelemente" insluit. In NW word die morfologiese status van dié elemente nie geëkspliseer nie.

Die genoemde elemente is volop in Afrikaans en enkele voorbeelde is in die aparte bylae vervat.

\section{2 "Woordelemente" versus affikse}

Die woordelemente van Griekse of Latynse oorsprong kan soos affikse aan stamme gekoppel word (Bauer 1983: 213). Die probleem kom egter by gevalle waar, wat op die oog af na affikse lyk, met ander affikse verbind om woorde te vorm. Dit kan die taalkundige hoofbrekens besorg, want voor- en agtervoegsels word juis gedefinieer in terme van hul verbindbaarheid met stamme of woorde.

Leksikale items soos byvoorbeeld astrografie, bioskoop, chiropodie, elektroliet, filosofie, hematosiet, ens. kan nie morfologies sinvol ontleed word as ' $n$ mens aanvaar dat woordvormingselemente soos astro-, bio-, chiro-, elektro-, filo-, hemaenersyds of -grafie, -skoop, -podie, -liet, -sofie en -siet andersyds affikse is nie.

Bauer (1983: 214) sê dan ook tereg dat vanweë hul unieke optrede, die sg. "combining forms" of "woordelemente" nie sonder meer as affikse beskou kan word nie. Hy onderskei tussen "Final Combining Forms (FCFs)" en "Initial Combining Forms (ICFs)". 
Combrink (1989: 248) noem dusdanige verbindings "tegnosamestellings". Hy sê naamlik dat tegnosamestellings gewone samestellings is waarvan die eerste stam 'n tegnostam is en die tweede stam vry (vgl. geopolities, kardiovaskulêr, kubofuturisme, neurokliniek, teledata, ens.) of gebonde (vgl. antroponimie, dramatologie, ekologie, Sowjettoloog, toponimie, ens.) kan wees. Wat tegnosamestellings betref, sal daar vir die doel van die bespreking tussen begin(ICFs) en eindkomponente (FCFs) onderskei word. Dié elemente verskil op die volgende maniere van affikse.

\subsubsection{Morfologiese verskille}

Aan die morfologiese verskille wat reeds vlugtig uitgewys is, kan die volgende toegevoeg word. In die eerste plek kan eindkomponente met beginkomponente verbind, terwyl dit nie vir gewone agtervoegsels moontlik is nie (Bauer 1983: 214). Dit blyk dujdelik uit die onderstaande voorbeelde:

hidrofiel; hidrofiet; hidrofoon; hidrograaf; hidroskoop

"hidroaan; "hidrobaar; "hidrodom; "hidroheid; "hidroskap

Uit die voorbeeldmateriaal (kyk bylae) blyk dit boonop dat beginkomponente feitlik altyd op -o eindig, behalwe as hulle met ' $n$ formans verbind wat met 'n vokaal begin. As ' $n$ betrokke komponent nie op -o uitgaan nie, is dit soms moontlik om daarvan ' $n$ beginkomponent te maak deur $-o$ by te voeg (Bauer 1983: 24). Vergelyk die volgende voorbeelde:

$\begin{array}{llll}\text { leksikon } & > & \text { leksiko- } & + \\ \text { neger } & >\text { negro- } & + \text {-fiel } \\ \text { film } & >\text { filmo- } & + \text {-teek }\end{array}$

Die wyse waarop beginkomponente met eindkomponente verbind, maak dit verder moontlik om eersgenoemde as 'n afsonderlike groep te beskou. Wat allereers opvallend is, is dat die meerderheid Afrikaanse voorvoegsels (soos Bauer dit ook vir Engels aantoon) op konsonante eindig en dus vanweë die genoemde fonologiese beperking nie met eindkomponente kan verbind nie. Vergelyk die voorvoegsels: aarts-, her-, mis-, oer-, on-, ont-, ver-, wan-, ens. Dit lyk dus of eindkomponente se optrede beperk is tot 'n kombinasie met eerste

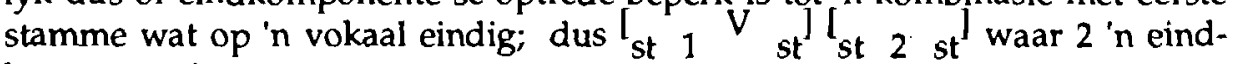
komponent is.

Selfs die voorvoegsels wat op vokale eindig, kan nie met eindkomponente verbind nie (Bauer 1983: 215) en daarom is die volgende leksikale items onmoontlik:

"akraat; "antefiel; "antigraaf; "befobie; "prelogie; "kogram; ens. 
Terwyl voorvoegsels se kombinasiemoontlikhede dus beperk is, wil dit voorkom asof beginkomponente ' $n$ groter morfologiese valensie het. Maar beginkomponente laat hulle nie sonder meer klassifiseer nie. Bauer (1983: 215) verwys na die woordelemente hiper-en super- (beginkomponente) wat as gedeeltelike sinonieme beskou moet word. Beide kan beteken "in baie hoë mate; buitengewoon, oormatig, uitermate". Nietemin wil dit voorkom asof hiper- meer geredelik met eindkomponente verbind as wat dit met super-die geval is. Vergelyk in dié verband hiperplasie, hipertensie, hipertonie en hipertrofie met superfyn, superbelasting en supermark, ens.

Die onderskeid tussen begin- en eindkomponente en affikse kan dus op morfologiese gronde geregverdig word.

\subsubsection{Semantiese verskille}

In die meeste gevalle bestaan daar 'n semantiese verskil tussen beginkomponente en voorvoegsels, maar dis moeilik vaspenbaar. Bauer (1983: 215) sê dat dit lyk asof beginkomponente betekenismatig meer bied as voorvoegsels. Die semantiese "lading" van woordelemente is egter nie absoluut meetbaar nie. Voorvoegsels soos pre- en sub-kan met onderskeidelik "voor" en "onder" verklaar word, terwyl sosio- moeilik verklaarbaar is sonder 'n verwysing na die samelewing of gemeenskap en eko- sonder dat daar van die ekologie of omgewing melding gemaak word. Ander beginkomponente is weer nes voorvoegsels met 'n enkele leksikale item vervangbaar. Vergelyk bio- ("lewe"), hidro("water") en pseudo- ("skyn"), ens. Affikse soos mini- en -isme bied op hulle beurt betekenismatig so baie dat hulle tot selfstandige woorde ontwikkel het.

Uit bogenoemde blyk dit dat dit nie moontlik is om op semantiese gronde 'n waterdigte skeiding tussen affikse en woordelemente van vreemde oorsprong te tref nie. Maar só 'n skeiding is dikwels ook nie tu'ssen affikse en gewone woorde moontlik nie; vgl. on- en nie- in bv. onduidelik en nie-duidelik. Omdat affikse morfeme is, het hulle betekenis. Dieselfde betekenis kan ook as leksikale elemente geleksikaliseer word, naas die leksikalisering van subleksikale elemente.

Sommige neo-klassieke komposita of tegnosamestellings tree soos endosentriese komposita op, terwyl afleidings met voorvoegsels nie noodwendig dié endosentriese verhouding weerspieël nie. By die leksikale items astrofisika en biochemie tree die tegnostamme of beginkomponente as bepalers op van die slotstamme wat die semantiese kerne is. Dié optrede bewys die stamstatus van die beginkomponente. By die afleiding ontwater is die voorvoegsel ont-nie ' $n$ tipe water nie, maar 'n hereksamen is wel 'n tipe eksamen. Dié hiponimiese verhouding geld egter nie sonder uitsondering nie en is ook nie tot dié tipe woordvormingsproses beperk nie. Bauer (1983: 215) wys daarop dat 'n pseudosuur juis nie 'n soort suur is nie, maar dat 'n aartsbiskop wel 'n soort biskop is.

Bauer (1983: 215) gee toe dat die woordelemente van Griekse en Latynse herkoms as gebonde stamme beskou sou kon word (soos Combrink ook aan- 
dui), maar hy verkies om die genoemde.elemente te aanvaar vir wat hulle is, naamlik elemente uit die Klassieke tale wat in Engelse woordvormingsprosesse benut word. In moderne Engels (en ook dikwels as leenvertalings in Afrikaans) is die produkte van dié woordvormingsproses volop. Bauer (1983: 215) wys tereg daarop dat alhoewel telefoon en televisie uit Griekse elemente bestaan, die sake waarna die betrokke leksikale items verwys, vir die antieke Grieke onbekend was. Vandaar die benaming "neo-klassieke" komposita.

\subsection{Leksikografiese aspekte}

Die onvermoë van taalkundiges om oor die morfologiese status van die genoemde woordelemente uitsluitsel te gee, veroorsaak dat die leksikografiese hantering van sodanige subleksikale items nie op 'n suiwer linguistiese grondslag geplaas kan word nie. Die leksikografiese hantering van die Griekse en Latynse woordelemente is aan die hand van dertig voorbeeldwoorde (kyk bylae) bestudeer. Die steekproef bestaan uit vyftien beginkomponente en vyftien eindkomponente. ' $n$ Vergelyking is getref tussen die hanteringswyse van die Verklarende Handwoordeboek van die Afrikaanse Taal (voortaan HAT) en die Nasionale Woordeboek (voortaan NW). Die volgende voorlopige gevolgtrekkings is gemaak.

(a)

Al vyftien beginkomponente is in HAT opgeneem, terwyl NW elf van die genoemde beginkomponente bevat. Wat die beginkomponente betref, lyk dit asof die woordeboeke 'n. verteenwoordigende groep opgeneem het.

(b) Slegs ses eindkomponente is in HAT opgeneem, terwyl NW geen eindkomponent insluit nie. Wat eindkomponente betref, bied HAT en NW nie 'n realistiese weergawe van hul gebruiksfrekwensie nie.

Bogenoemde tendens kan toegeskryf word aan die tradisionele woordgebaseerde struktuur van woordeboeke en die neiging om aan eerste stamme Jeksikografiese prominensie bo slotstamme te verleen. Leksikale items kleiner as woorde het maar eers onlangs lemmastatus gekry en die klem val steeds sterker op eerste stamme as slotstamme. Hieraan sal leksikograwe in die toekoms meer aandag moet gee - veral waar produktiewe woordvormingselemente aan die orde is.

\subsubsection{Lemmastatus}

Begin- en eindkomponente moet as subleksikale lemmas ingesluit word, omdat hulle in die meeste gevalle unieke komponente is wat slegs ' $n$ stamoptrede het (as 'n mens aanvaar dat dié woordvormingsproses op kompositumvorming neerkom) en nie ook as afsonderlike leksikale lemmas opgeneem word nie. 
Soms wil dit voorkom asof woordelemente soos bv. -chroom, -graaf,-gram, ens. ook as selfstandige woorde kan optree, maar die leksikale items chroom ("blink, harde, bros metaal"), graaf ("spitwerktuig" of "adellike titel") en gram ("klein massa in die metrieke stelsel") hou betekenismatig geensins met -chroom ("kleur"), -graaf ("geskrif") en -gram ("tekening") verband nie. By dié streeplemmas sal 'n kruisverwysing na die leksikale lemma dus ontbreek, soos wat dit ook in HAT die geval is. Op dié wyse word bevestig dat daar van verskillende leksikale items sprake is.

\subsubsection{Kruisverwysings}

In teenstelling met die bogenoemde subleksikale items hou die woordelemente homo-, outo, -fobie, -foon en -manie wel betekenismatig verband met die leksikale variante homo, outo, fobie, foon en manie. Die betekenis van die selfstandige woorde is herleibaar na die van die woordelemente, want eersgenoemde het deur middel van 'n proses van "backformation" of "Rückbildung" uit neo-klassieke komposita ontstaan. Combrink (1989: 230) noem die proses "inkorting" en verwys na die verselfstandiging van tegnostamme soos bv. Afro, gastro, kilo, makro, mikro en neuro. Deur van kruisverwysings gebruik te maak, kan die leksikograaf sodanige verwantskap aantoon.

By die HAT-lemma homo staan bloot "Homoseksuele individu" en by outo "Motor", sonder enige aanduiding dat die genoemde leksikale items normaalweg as eerste lid van 'n kompositum optree, soos bv. in homoseksueel of outomobiel. Homo en homo-, asook outo en outo- is variante optredes van dieselfde leksikale item. Normaalweg kan die woordvariant as die ongemerkte optrede en die stamvariant as die gemerkte optrede beskou word. Dit wil voorkom asof by tegnostamme die teenoorgestelde geld. Die woord variant is uiters gemerk, omdat dit die resultaat van "Rückbildung" is. By die woordvariant behoort 'n kruisverwysing na die kompositum waaruit hy gevorm is, verstrek te word. Waar die woordvariant ' $n$ wyer waarde het as net die verkorting uit één kompositum, moet die kruisverwysing na die streeplemma gemaak word. By homo moet homoseksueel en by outo moet outo- as verwysing optree.

By die HAT-lemma fobie is die inligting vollediger, maar terwyl outo- as streeplemma optree, is dit nie met -fobie die geval nie. By die leksikale lemma fobie behoort -fobie as verwysing op te tree. Die leksikale lemma word soos volg gehanteer:

"fobie, (-ë). Sieklike vrees - veral gebruik as tweede lid van samestellings ... Agora-, bakterio-, hidro- of hipsofobie. [As simpleks < G. phobos vrees; as tweede lid van ss. < G. -phobia vrees vir die genoemde saak]."

Die subleksikale item -foon word weer wel as streeplemma ingesluit en soos volg verklaar: 
"-foon. Tweede lid van enkele samestellings afgelei van G. phone geluid, klank, bv. tele-, dikta-, mikrofoon."

Terselfdertyd word in die woordeboekartikel van die leksikale lemma foon te kenne gegee dat dié leksikale item deur "Rückbildung" gevorm is. Vergelyk: "foon ... Verkorte vorm, veral in die spreektaal, van telefoon."

Die leksikale item manie word opgeneem en verklaar, maar sonder enige aanduiding dat hy as tweede lid van 'n kompositum (vgl. xenomanie, monomanie, ens.) ook 'n stamoptrede het. Die subleksikale lemma -manie ontbreek derhalwe. Die polisemiese waardes van manie word soos volg aangedui:

"manie ... 1. Sieklike sug, drang tot iets sonderlings; oordrewe voorliefde vir iets ... 2. (psigiat.) Geestestoestand gekenmerk deur onbeheerde emosionele, verstandelike of senuweeprosesse; opwinding van psigotiese afmetings gekenmerk deur geestelike en liggaamlike ooraktiwiteit, verwarrende gedrag en eksaltasie."

Bogenoemde inskrywing sou ewe goed in 'n psigiater se handleiding of mediese handboek kon gestaan het, maar of sodanige definiëring van 'n algemene leksikograaf vereis word, is te betwyfel. Uit die voorafgaande bespreking blyk dit duidelik dat die gebruik van kruisverwysings by neo-klassieke lemmas en die komposita met neo-klassieke stamme veel te wense oorlaat.

\subsubsection{Etimologie}

HAT toon feitlik deurgaans die etimologie van die vreemde woordelemente aan, terwyl dit by NW ontbreek. Dit is waardevolle inligting vir die woordeboekgebruiker en kan hom in staat stel om die onverklaarde lemmas of vreemde leksikale items (dikwels vakwoorde) wat nie in die woordeboek opgeneem is nie, self te interpreteer. Sodanige inligting kan dus ' $n$ enkoderende waarde hê.

\subsubsection{Fonologiese inligting}

Wat fonologiese leiding betref, gee HAT soms 'n aanduiding van hoe variasie by beginkomponente fonologies gemotiveer word. Vergelyk die volgende inskrywing:

"hidro-. Ook hidr- (voor vokale) ..."

Ongelukkig is HAT nie konsekwent in sy toepassing daarvan nie. Vergelyk die volgende inskrywings:

"hipo-. Ook soms hip-". en "filo-. Ook fil-." 
In laasgenoemde gevalle word die afwesigheid van die -o nie verklaar nie.

NW bied weer waardevolle fonologiese leiding deur die klempatrone van dié woordvormingsprodukte aan te dui. Dit blyk uit die volgende inskrywings:

"bio-: met betrekking tot lewende organismes, tot wat lewe. Bioche'mie, -'fisika, -morfolo'gie."

"hidro-: water, vloeistof. Hidroteg'niek, -tera'pie."

"hiper-: in baie sterk of oordrewe mate. 'Hiperanalities, -beleef, -krities, -modern."

Sodanige inligting is vir die woordeboekgebruiker belangrik omdat die klempatrone van neo-klassieke komposita nie altyd sistematies voorspelbaar is nie, soos wat dit inderdaad ook met ander komposita die geval is.

\subsubsection{Eenvormigheid}

Onduidelikheid oor die morfologiese status van die vreemde elemente blyk uit HAT se hantering van die subleksikale lemmas bio-, hiper-, meta-, super-, -gram en -skoop om maar enkeles te noem. Vergelyk die leksikografiese hantering van die volgende subleksikale items:

1 "bio-. Met betrekking tot wat lewe ... [G. bios lewe]."

2 "hiper-. Voorvoegsel uit G. huper, met die betekenis ..."

3 "meta-. Woordelement met die bet. ... [C. meta]."

4 "super-.... (L.) Eerste lid van ss. met die bet...."

5 "-gram. Woordelement afgelei van G. gramma met die betekenis ..."

6 "-skoop. Agtervoegsel afgelei van G. skopos ... met die bet. ..."

By 1 word (soos deurgaans in NW) geen aanduiding van die morfologiese status van die leksikale item gegee nie. By 2 en 6 word daama verwys as affikse. By 3 en 5 word "woordelement" gebruik en by 4 word met die verwysing "Eerste lid van ss." geimpliseer dat die betrokke element wel 'n stam is en dus betrokke is by kompositumvorming.

Dié hanteringswyse verwar die gebruiker. Dis nodig dat 'n eenvormige beskrywingspatroon gehandhaaf moet word, watter status die leksikograaf ook al aan dusdanige elemente wil toeken. Die status van die elemente moet boonop vanuit die taalkunde gemotiveer word.

\subsection{Slot}

Alhoewel HAT 'n groot groep Griekse en Latynse woordvormingselemente as streeplemmas akkommodeer, is dit nie duidelik op watter gronde insluiting 
berus nie. Die volgende beginkomponente is bv. nie in HAT opgeneem nie, maar is net so aktief in Afrikaans werksaam.

eko-. [G. oikos "huis"] soos in ekologie, ekonomie, ens.

lito-. [G. lithos "steen"] soos in litograaf, litoloog, litosfeer, ens.

orto-. [G. orthos "reg"] soos in ortodoks, ortografie, ortopedie, ens.

psigo-. [G. psyche "siel"] soos in psigoanalise, psigoloog, psigopaat, ens.

Komposita waarin die betrokke beginkomponente optree, is wel in HAT ingesluit en leksikografies bewerk. Sodanige hanteringswyse negeer die produktiwiteit van dié elemente en laat die leksikograaf terselfdertyd ruimte inboet wat meer oordeelkundig benut sou kon word.

Wat die leksikografiese hantering van neo-klassieke komposita betref, rus die verpligting op die leksikograaf om hulle so eenvormig en realisties as moontlik te benader. Daardeur word die sg. "moeilike" woorde vir die leek toeganklik gemaak.

\section{Pseudo-sintaktiese komposita}

\subsection{Inleiding}

In Afrikaans kom 'n tipe verbinding wat soos 'n sinsdeel lyk, maar ' $n$ ander soort funksie of ' $n$ besondere betekenis het, vry algemeen voor. Hierdie meerwoordige leksikale item vorm 'n ortografiese eenheid en kan as 'n soort kompositum beskou word. Sodanige verbinding, waarna voorts as 'n pseudo-sintaktiese kompositum verwys sal word, is boonop 'n betekeniseenheid wat dikwels deur ' $n$ enkele woord vervang kan word. Dié betekenis is nie af te lei uit die som van die samestellende dele se betekenis nie. 'n Pseudo-sintaktiese kompositum is dus ' $n$ enkele leksikonitem wat as sodanig vir insluiting in die woordeboek kwalifiseer. Die lemmakeuse van 'n leksikograaf moet immers 'n getroue weerspieëling wees van alle leksikale items waaruit die betrokke taal se woordeskat bestaan (Gouws 1989: 108).

\subsection{Leksikografiese hantering}

Sover dit die leksikografiese hantering van pseudo-sintaktiese komposita aangaan, geld alle reëls wat vir gewone leksikale items geld. Slegs verbindings wat geleksikaliseerde items is en deel uitmaak van die kernwoordeskat van Afrikaans, sal vir insluiting in 'n handwoordeboek in aanmerking kom. Geleentheidskomposita soos die volgende, sal nie sonder meer as afsonderlike lemmas opgeneem word nie: 


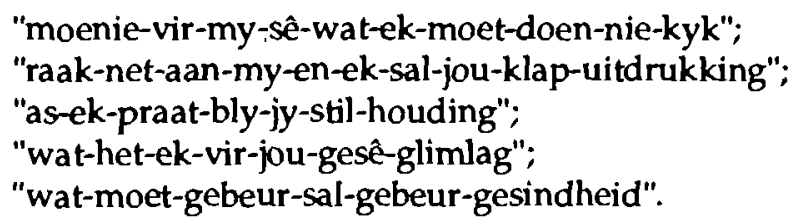

Die volgende verbindings is wel in HAT op hul alfabetiese plek opgeneem. Van diê verbindings verskyn 1, 7, 13, 14, 16, 18, 21 en 23 ook in NW. Dit is goeie leksikografiese praktyk.

1 alhonderd-en-tien ("Al is dit ook so; nogtans; almaskie.")

2 blinkblaar-wag-' $n$-bietjie ("Bladwisselende boom met blinkgroen blare en dorings op die takke.")

3 dop-en-dam ("[Minderwaardige] brandewyn en water.")

4 droog-my-keel ("Enigeen van 'n aantal plantsoorte ... waarvan die bessies ' $n$ vrank smaak in die keel veroorsaak.")

5 duiwel-in-die-bos ("Kosmos.")

6 dwars-in-die-weg ("1. Gebou wat dwars op 'n pad staan. 2. (fig.) Verkeerde, dwarskoppige mens.")

7 elf-en-dertigste ("Soveelste ... baie langsaam.")

8 hand-om-die-nek-hek ("Konsertinahek wat met 'n stuk ketting of draad aan 'n stuk hout om die bo-ente van die eerste hekspoor en die hekpaal toegehou word.")

9 help-my-krap ("Jeukende huiduitslag; jolliejeuk; lekkerjeuk; Skotse fietel.")

10 hou-jou-bek-wet ("Wet waardeur vryheid van spraak belet of aan bande gelê word.")

11 jan-in-die-sak ("Doekpoeding.")

12 jantjie-sonder-erg ("Onbekommerde persoon wat ongeërg sy gang gaan.")

13 jantjie-van-alles ("Iemand wat allerhande werkies kan doen; faktotum.")

14 jan-van-gent ("Groot seevoël met wit vere ... seegans.")

15 juffertjie-in-die-groen ("1. Gewilde tuinblom. 2. Drankie gemaak van brandewyn en suiker.")

16 kruidjie-roer-my-nie ("1. Baie gevoelige plant, met volop nektar, giftige blare en rooibruin blomme, ... 2. (fig.) Prikkelbare, liggeraakte, opvlieënde persoon.")

$17 \quad$ kyk-in-die-pot ("1. Man wat hom met kombuissake bemoei; potkyker. 2. (fig.) Onbeskeie, nuuskierige toeskouer wat hom graag met ander mense se sake bemoei.")

18 laag-by-die-gronds ("Nie hoogstaande, verhewe nie; platvloers.")

19 lelie-der-dale ("Lenteblom met 2 groot blare en spierwit, klokvormige blomme - sinnebeeld van reinheid.") 
ou-meid-onder-die-kombers ("Vleis in deeg gebak:"): oupa-pyp-in-die-bek ("Soort orgidee .... met perserige. blomme:waarvan die dun, dwars lip pypvormig ịs.") slinger-om-die-smoel ("Melksnyșels.")

23 wag-'n-bietjie ("Benaming vir enigeen van verskeie, struike en bome met haakdorings, veral die katdoring ... en haakdoring ... en ... (haak-

(- en-steek)."!)

\subsubsection{Semantiese aspekte}

Die volgende gegeweris blyk uit die genoemde data. Uit die 23 leksikale items is daar ag wat gebruik word om ina plante (vgl. $2,4,5,15,16,19,21$ en 23) en vier om na mense (vgl. 6, 12, 13 en 17) te verwys.. Een leksikale item kan op 'n mens of plant betrekking hê (vgl.:16). Daàr. is vyf leksikale items wat op kos en drank.(vgl. 3, 11, 15, 20 en 22) dui en slegs.een leksikàle itèm wat tot die dierewêreld (vgl. 14) behoort. Die ander vyf leksikale items (vgl. $1,7,9,10$ en 18) is nie so maklik klassifiseerbaar nie. Globaal beskou, lyk dit asof.pseudo-sintaktiese komposita veral gebruik word om na plante: of mense te verwys. Die genoemde komposita het 'n naamgewingsfunkșie en dié benoeming beskryf 'n bepaalde aspek van die saak.

Sodanige beskrywing het egter nie altyd 'n letterlike waardenie'. Soos wat dit met geleksikaliseerde uitdrukkings die geval is, is die :verhouding tussen die leksikale item en die saak waama dit verwỳs, dikwels metafóries. Dit geld byvoorbeeld die leksikale item dwars-in-die-weg iwat 'n koppige; verkeerde mens aandui. In ander gevalle is die metaforiese verband nie meer aantoonbaar nie en het die leksikale item, bv. jakkals-trou-met-wolf-se-urou-weer (gesê as daar tegelyk reën en sonskyn is), 'n geykte betekeniswaarde: Pseudo-sintaktiese komposita is dus nie "selfverklarend". nie en kort 'n uitvoerige leksikografiese bewerking.

By vier van die lemmas, naamlik dwars-in-die-weg, juffertjie-in-die-groen, kruidjie-roer-my-nie en.kyk-in-die-pot (vgl. 6, 15, 16 en 17) is polisemiese onderskeidings aangetoon en is daar tereg van die letterlike na die'meer figuurlike betekenisonderskeidings beweeg. .

\subsubsection{Konteksleiding}

Wat by die bewerking van die.HAT-lemma alhonderd-en-tien as hinderlik opval, is dat ' $n$ gepaste voorbeeldsin ontbreek. Dit is nie'vir die. oningewyde woordeboekgebruiker voldoende óm te: weet dảt dié leksikalè item "met "nogtans" of "almaskie" vervangbaar is nie..' $n$ Aanduiding van die sintäktiese optrede van dié ongewone verbinding sou waardevol wees." By' "n soortgelyke lemma, naamlik elf-en-dertigste, is wel voorbeeldsinne ter töeligting gebruik : 


\subsubsection{Kruisverwysings}

By die leksikale lemmas nogtans en almaskie word sinoniemdefinisies en voorbeeldsinne aangetref, maar ' $n$ kruisverwysing na alhonderd-en-tien ontbreek. Dit is 'n leemte.

Die leksikale lemmas duiwel-in-die-bos, jan-in-die-sak, jan-van-gent, kyk-indie-pot en slinger-om-die-smoel word onder andere met onderskeidelik kosmos, doekpoeding; seegans, potkyker en melksnysels verklaar. Waar laasgenoemde leksikale items as selfstandige lemmas optree, kom tereg kruisverwysings na die meerwoordige leksikale lemmas voor. 'n Jantije-van-alles kan met "faktotum" verklaar word, maar by die lemma faktotum kom geen kruisverwysing na jantjie-van-alles voor nie. Dit is wenslik dat dit wel bygevoeg word.

HAT se hantering van die lemmas blinkblaar-wag-'n-bietjie en wag-'n-bietjie(-boom) is eweneens onbevredigend. $\mathrm{Al}$ is die genoemde leksikale items nie absoluut sinoniem: nie,. sou.'n mens by blinkblaar-wag:' $n$-bietjie die inskrywing 'Vgl. WAG-'N-BIETJIE". en by.. wag-'n-bietjie(-boom) die inskrywing "Vgl. BLINKBLAAR-WAG-'N-BIETJIE". verwag. By die lemma-wag-'n-bietjie is daar die implisiete verwysing na haakdoring, haak-en-steek en katdoring (vgl. 23). By haakdoring en haak-en-steek is daar wel 'n kruisverwysing na wag-' $n$-bietjie', maar by katdoring nie. Die enigste kruisverwysing na blinkblaar-wag-'n-bietjie kom by haakdoring voor. By blinkblaar-wag-'n-bietjie is daar geen verwysing na enige van die genoemde lemmas nie. Die woordeboekgebruiker sou by 'n konsekwente hanteringswyse baat vind.

\subsubsection{Getalsaanduiding}

Waar pseudo-sintaktiese komposita as leksikale lemmas optree, word hulle in HAT meestal sonder enige meervoudsaanduiding gelys, maar wat staan die woordeboekgebruiker te doen as hy die volgende wil sê:

"Jan en sy pa is albei dwars-in-die-wee"?

By jantjie-sonder-erg skyn dit makliker te wees:

"Ek is moeg daarvan om met julle jantjies-sonder-erg te sukkel!"

Hoekom word die meervoud by die volgende geval gegee en nie ook by die ander nie?

"Julle kruidjie-roer-my-nies moet maar eenkant toe staan!"

Oor die bogenoemde kwessies sou die leksikograaf waarskynlik uitsluitsel kon gee. Sommige pseudo-sintaktiese komposita laat wel ruimte vir getalsaanpassings, sonder dat hul "idiomatisiteit" daardeur verlore gaan. Die leksikograaf 
moet nie ' $n$ rigoristiese benadering volg nie, maar hom deur werklike taalgebruik laat lei.

\subsection{Slot}

Alhoewel die insluiting van meerwoordige leksikale items oorwegend semanties gemotiveer is, mag die leksikograaf nie toelaat dat sy preokkupasie met "sense" of "meaning" die oorhand kry nie. Hierteen waarsku Sinclair (1984: 4) baie pertinent. Die opname van pseudo-sintaktiese komposita moet veral ook leksikologies gemotiveer kan word.

\section{Verwysings}

Bauer, L. 1983. English Word-formation. Cambridge: Cambridge University Press.

Botha, T.J.R. et al (Red.). 19892. Inleiding tot die Afrikaanse taalkunde. Pretoria: Academica.

Combrink, J.G.H. 1989. Afrikaanse morfologie: 'n oorsig. Botha, T.J.R. et al (Red.). 19892: 220-254.

De Villiers, M. e.a. 1987. Nasionale Woordeboek. Kaapstad: Nasou.

Gouws, R.H. 1989. Leksikografie. Kaapstad: Academica.

Hartmann, R.R.K. (Red.). 1984. LEXeter '83 Proceedings. Tübingen: Max Niemeyer.

Odendal, F.F. 19792. Vèrklarende Handwoordeboek van die Afrikaanse Taal. Doomfontein: Perskor. Sinclair, J.M. 1984. Lexicography as an Academic Subject. Hartmann, R.R.K. (Red.). 1984: 3-12. 


\section{Bylae}

ELEMENT

1 astro-

2 bio-

3 chir(o)-

4 elektro-

G. élektron

"amber"

5 filo-

6 galvano-

7 hemato-

G. philos

It. Na Luigi Galvani wat die eerste die verskynsel van chemies opgewekte stroom beskryf het. "wat elektriese stroom deur chemiese werking opwek"
G. haima
"bloed"

8 hidro-

G. hudor

"water"

9 hiper-

G. huper

"bo"

10 hipo-

G. hupo

"onder"

11 homo-

G. homos

\section{KOMBINASIE- MOONTLIKHEDE}

astrofisika;

astrografie;

astrologie

biochemie;

biografie;

bioskoop

chiromansie;

chiropodie;

chirurgie

elektroanalise;

elektrochemie;

elektroliet

filologie;

filosel;

filosofie

galvano-chinurgie;

galvanometer;

galvanoskoop hematofobie;

hematologie;

hematosiet

hidrochloride;

hidrodinamies;

hidrofiel

hiper-Afrikaans;

hiperbool;

hipersensitief

hipochondries;

hipodermies;

hipofonie

homochromaties;

homoniem;

homoseksueel 


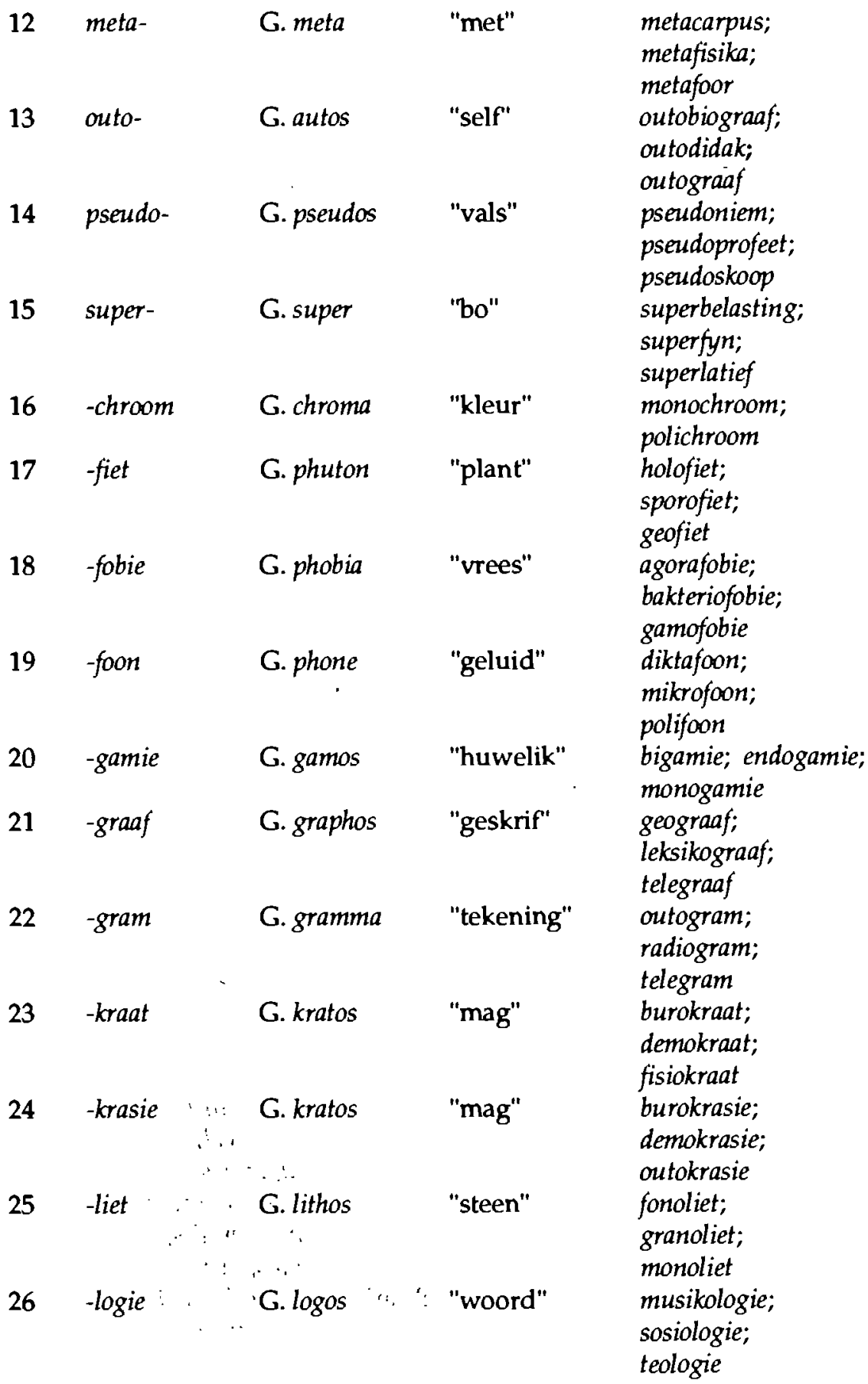


$27 \quad-m a n i e$

G. mania

"raserny"

bibliomanie;

dipsomanie;

28 -metrie

G. metrein

"meet"

kleptomanie

29 -patie

G. pathos

"lyding"

fotometrie;

geometrie;

psigometrie

$30 \quad-s k o o p$

G. skopos

"kyker"

heteropatie;

simpatie;

telepatie

mikroskoop;

stetoskoop;

teleskoop 